\title{
The Effect of Foreign Direct Investment from Austria on Skilled and Unskilled Labor in Bosnia and Herzegovina
}

\author{
Safet Kurtovic (Corresponding author) \\ Faculty of Management and Business Economics, University of Travnik \\ Aleja Konzula 5, 72 270, Travnik, Bosna and Herzegovina \\ Tel: 387-61760-955Ｅ-mail: safetkurtovic@yahoo.com \\ Haris Dacic \\ Faculty of Management and Business Economics, University of Travnik \\ Aleja Konzula 5, 72 270, Travnik, Bosna and Herzegovina \\ E-mail: haris.dacic@fmpe.ba
}

\author{
Sead Talovic \\ Ministry of Foreign Trade and Economic Relations of Bosnia and Herzegovina \\ Musala 9, 71 000, Sarajevo, Bosnia and Herzegovina \\ E-mail: sead.talovic@bih.net.ba
}

Received: January 24, 2016

Accepted: February 17, 2016

doi:10.5296/ber.v6i1.8924

URL: http://dx.doi.org/10.5296/ber.v6i1.8924

\begin{abstract}
Foreign direct investment (FDI) is considered a major factor in the process of a country's economic development. The presence of FDI in host countries has multiple effects on their economic development. One of these effects pertains to the change in organization and composition of labor market. With that in mind, this paper studies the effect of FDI inflow from Austria on the labor market in Bosnia and Herzegovina $(\mathrm{B} \& \mathrm{H})$. It analyzes the time series data for the period 2005 - 2014. The research of the paper is divided into two parts. The first part studies the effect of certain independent variables on the increase in real average
\end{abstract}


wages of skilled and unskilled labor. The second part examines the effect of certain independent variables on the increase in the number of skilled and unskilled workers. This paper applies the North-South Model and OLS Regression. The research has shown that the impact of the majority of independent variables on dependent variables is statistically significant.

Keywords: FDI, Skilled labor, Unskilled labor, Labor market, Average wage

\section{JEL Classification: F20 F21 F23}

\section{Introduction}

FDI appear most frequently in the form of greenfield investments and cross-border mergers and acquisitions. Greenfield investments rely on the internal capabilities of the multinational enterprise to build a new factory in a foreign country, while cross-border mergers and acquisitions imply transfer of ownership of an existing asset (Davies et al., 2015). FDI are, for the most part, made in the form of cross-border mergers and acquisitions, and to a lesser extent in the form of greenfield investments (Hakkala et al., 2007; Hakkala et al., 2010). Apart from this, FDI can be horizontal and vertical in nature. Vertical FDI cause an increase in domestic demand for production factors and export. On the other hand, horizontal FDI cause reduction in export from the company's country of origin. In the case of vertical FDI, there is a relative increase in demand for skilled labor in the company's country of origin and unskilled labor with lower wages in the host country. However, horizontal FDI cause an increase in demand for skilled labor in the company's country of origin, which indirectly leads to changes in income distribution (Cuyvers, 2010; Davies and Desbordesz, 2012; Mattes, 2010).

In order to attract FDI, it is very important to pay attention to lifelong upgrading of workers' skills and competences. The rationale behind this is threefold. First, technological and structural changes bring new jobs and skills at such a rate that the slow inclusion of young skilled workers might not suffice to satisfy the demand for new qualifications, thereby increasing the risk of skill shortages that may ultimately stop the employment. Second, less skilled workers face higher unemployment prospects, which increases unemployment gap. Third, as skills become obsolete more quickly than workers retire from the labor force, there is a strong risk of older workers losing their current jobs due to lack of competences, without providing them with the opportunity to requalify or transfer to new jobs (Bassanini, 2004).

FDI affect human capital development in two ways. In the short run, presence of foreign companies positively affects the labor market through transfer of knowledge to local workers i.e. through organizing seminars and the like. In the long run, through FDI, foreign companies help improve the macroeconomic environment in the host country by increasing workers' productivity, ensuring stable source of capital and paying host country taxes, thus contributing to the ability of host countries to fund education. Foreign companies particularly influence labor supply by helping the host country to enhance education infrastructure in terms of curriculum choices and vocational training (Slaughter, 2002a; Slaughter, 2002b; Checchi et al., 2007). In the labor market we distinguish between non-production and 
production workers. Non-production workers are present in the services sector, while production workers are found in the manufacturing sector. Non-production workers are better educated and skilled, whereas production workers are less educated and unskilled. These two categories of workers are better known as skilled and unskilled, i.e. white collar and blue collar workers (Feenstra, 2007).

During the last three decades, there has been a worldwide increase in demand for skilled workers. Four factors have contributed to this increase. The first factor pertains to the ever-increasing presence of high technology in the manufacturing process, the use of which requires skilled labor (Feenstra, 2007). The second factor is related to changes brought about by globalization process. The third factor has to do with the international production fragmentation and outsourcing (Feenstra, 2007; Borjas and Ramey, 1993). The fourth factor is the fact that an increase in import competition from low-wage (Feenstra and Hanson, 1995; Feenstra and Hanson, 1996).

The official view is that transition countries have an educated labor force. This conclusion is based on the fact that these countries have made significant investments in the education of their labor force i.e. that they have a high percentage of skilled workers relative to their total population. In transition countries, certain specializations and technical skills had been foreseen according to the requirements of planned economy and, as such, became unusable in the market economy. The moment the need for company restructuring arose, low adaptability and mobility of workers were observed. At one time, increased demand for skilled labor surpassed labor supply in the market. Lack of skilled labor directly affects the production by preventing companies from meeting their demands and using available resources. Indirectly, lack of skilled labor hinders innovations and use of new technologies. Discrepancy between skills demand and supply i.e. between what companies require and what educational and training institutions offer in the labor market, has negative implications in terms of wasting public and private investments in human capital., which in turn negatively affects the labor market development. Also, the difference between wages was small, which had a negative impact on workers' motivation and productivity (Commander and Kollo, 2004; Gashi and Adnett, 2012; Tan et al., 2007).

Transition of Western Balkan economies encompassed structural changes, privatization and restructuring of state-owned companies. These processes lead to loss of jobs in state-owned companies and creation of an army of unskilled workers. There is a discrepancy between supply and demand for skills in the labor markets of the Western Balkan countries. This discrepancy is thought to be caused by several factors. Firstly, obsolete workers' skills inherited from the former self-governance system have become superfluous due to introduction of new technologies through restructuring of state-owned companies. Secondly, company owners invest very little in on-the-job-training due to uncertainty induced by the poor investment climate. Thirdly, old skills have become obsolete due to the persistence of long-term unemployment. Fourthly, re-skilling has been inhibited by the low provision of adult education and life-long learning opportunities (Bartlett and Arandarenko, 2012).

Over the last two decades, B\&H has achieved modest results in terms of FDI inflow. One of 
the reasons for this is the unreformed labor market. Therefore, this paper's main objective is to study the following issues: increase in the average real wage for skilled labor; increase in the average real wage for unskilled labor; increase in the number of skilled and unskilled workers. Additionally, the objective of this study is to show whether FDI inflow from Austria as B\&H's most significant investment partner has positively affected the change in labor market structure during the last two decades. The answer to this question has been reached by studying the effect of independent variables on average real wages of skilled and unskilled workers, as well as on the increase in the numbers of skilled and unskilled workers. The research has shown that independent variables such as the average real wage for unskilled labor, gross fixed capital formation, industry value added, number of skilled workers and FDI inflow from Austria have a statistically significant effect on the increase in average real wages for skilled and unskilled labor. Apart from this, it has been determined that independent variables such as the number of persons who completed elementary, secondary and tertiary education; the number of employees in industry, services and agriculture sector have a statistically significant effect on the increase in the number of skilled and unskilled workers in $\mathrm{B} \& \mathrm{H}$.

The paper consists of sections as follows: Section 2 provides an overview of literature or research closely related to this paper's research subject; Section 3 describes the economic model; Section 4 describes econometric techniques and databases used in the research; Section 5 provides the empirical results of the research and, finally, Section 6 contains the conclusion.

\section{Literature Review}

Feenstra and Hanson $(1995 ; 1996)$ studied the impact of FDI on labor demand and increase in wages in the case of Mexico. Their research has shown that American FDI strongly affected the demand for educated labor force in Mexico and the USA. The results of the research ran contrary to the previously held view that FDI would lead to an increase in the demand for production workers. Markusen and Venables (1996) concluded that FDI lead to removal of barriers to relocation of production based on unskilled labor from developed to undeveloped countries. They also determined that there was an increase in the rate of return to skilled labor in both the country of origin of FDI and the host country, i.e. that there was an increase in wage gap between skilled and unskilled workers. Analyzing the case of the USA and Canada, Murphy et al., (1998) concluded that there was an increase in wage inequality in the case of workers who had completed secondary and tertiary education. This increase in wage inequality was caused by technological changes leading to reduction in demand for less educated workers i.e. leading to an increase in the number of persons who completed secondary and tertiary education. Lipsey (2002) determined that foreign companies pay higher wages than local companies for several reasons. Namely, foreign companies are bigger, they have better educated and more skilled workers, their production is more capital intensive, they are more productive and more strongly involved in trade flows than the local companies. Analyzing the case of Poland, Hungary and the Czech Republic, Bruno et al., (2004) studied the effect of FDI on wage inequality and demand for educated labor. In Hungary and Czech Republic no significant oscillations were observed owing to a higher FDI inflow and 
implemented reforms as well as engagement of multinational companies in the process of providing training. In Poland, however, there was an increase in wage difference in favor of educated labor. Commander and Kollo (2004) studied the issue of demand for educated labor in transition countries such as Hungary, Romania and Russia. The study has shown that the aforementioned countries were facing the problem of restructuring of companies i.e. shutting down of old state-owned companies and opening of new ones, which resulted in creation of an army of unemployed workers with outdated skills. Following the implementation of reforms, a number of newly started companies in Hungary and Romania managed to recruit over 50 percent of unemployed workers and offer training for workers with higher education. This was particularly the case in services sector where the demand for non-production workers who had completed tertiary education went up.

Castellani et al., (2006) used the sample of 108 Italian companies that invest abroad to study the effect of educated workers' skill upgrading. They found that by relocating production to transition countries they create the effect of skill upgrading in workers with tertiary education, while this effect was significantly weaker in the case of labor intensive production abroad. Cuyvers et al. (2010) studied the effect of FDI from Belgian companies - which invested in developed and developing countries - on demand for labor. The study has shown that the countries with FDI inflow registered a decline in demand for less skilled workers, while, in turn, they saw an increase in demand for skilled workers. Hakkala et al., (2010) examined the effect of multinational companies on labor demand elasticity. Their research has shown that multinational companies had a more elastic demand for labor of 0.45 percent compared to the local companies whose labor demand elasticity was only 0.3 percent. Additionally, they found that ownership structure did not affect the labor demand elasticity. However, in the case of a takeover of the foreign company, there was an increase in elasticity of the demand for workers with secondary education. Mattes (2010) determined that FDI had a positive effect on workers with elementary and tertiary education. Tomiura et al., (2011) studied the relationship between skilled and unskilled workers in Japan. They concluded that there was an increase in the number of skilled non-production workers compared to the number of unskilled workers in offshoring companies. Particularly, the number of skilled workers in subsidiaries abroad increased, while that was not the case in the parent companies in Japan.

Using OECD countries as an example, Davies and Desbordes (2012) analyzed the effect of greenfield FDI and acquisitions on labor demand and skill upgrading. The analysis has shown that greenfield investments had a greater effect on demand for workers with secondary and tertiary education than acquisitions. This effect was particularly noticeable in the high-tech services sector, while the demand for production workers remained unchanged. Goczek (2013) determined that foreign companies in the Central and Eastern European more often encounter difficulties associated with an insufficiently educated labour force in relation to the local state-owned or privately owned companies. Foreign companies required and recruited better educated labor force than the local companies. Almeida and De Faria (2014) studied the shortage of skilled labor force in Thailand and Malaysia. With the aim of resolving the issue of the lack of skilled workers, they measured the effect of on-the-job training of workers and concluded that it positively impacted the increase in wages. Wage returns were 7.7 percent in 


\section{Macrothink}

Business and Economic Research

ISSN 2162-4860

2016, Vol. 6, No. 1

Malaysia and 4.5 percent in Thailand and 4.5 percent. This effect was higher for workers with secondary education compared to the ones with elementary education.

\section{The Model}

The economic model is based on Feenstra and Hanson (1995) North-South model. In this paper's research, there has been a slight modification to the model in terms of observing economies of a developed country and a transition country respectively. We assume that both countries have a fixed amount of skilled labor $\left(H_{i}\right)$, unskilled labor $\left(L_{i}\right)$ and capital $\left(K_{i}\right)$.

Then, we assume that we produce a final product $x$ and denote it $c \in[0,1]$ (Feenstra and Hanson, 1995). The production of each product unit requires skilled labor, unskilled labor and capital. Unskilled and skilled labor do not substitute for each other, while capital substitutes for labor with a unitary substitution elasticity. Production of one output unit $i$ requires one unit of unskilled labor and h (i) of skilled labor and, thus, we specify the unit cost function of intermediate good $i$,

$$
c(i)=\left[w_{L}+w_{H} h(i)\right]^{\alpha} r^{1-\alpha}
$$

where $w_{L}$ and $w_{H}$ denote wages of unskilled and skilled labor, $\mathrm{r}$ denotes rate of return to capital, and $\alpha$ is a parameter. We get the final product according to Cobb-Douglas production function (Feenstra and Hanson, 1995),

$$
\ln Y=\int_{0}^{1} \alpha(c) \ln x(c) d c
$$

where $\int_{0}^{1} \alpha(c) d c=1$. Then, we assume that $c\left(w_{L^{\prime}}, w_{H_{a}} r i c\right)$ represents minimum costs of production of a product unit $x$, specified as

$$
c\left(w_{L}, w_{H} r i c\right)=\beta\left[w_{L} \alpha_{L}(c)+w_{H} \alpha_{H}(c)\right]^{\alpha_{r}} r_{i}^{1-\alpha}
$$

where $\beta$ is constant. We also work on the assumption that there is mobility between the skill levels. By organizing education and training programs, companies enable unskilled workers to requalify into skilled workers. Increase in skilled labor supply brings about a change in wages. Accordingly, we start with Shephard's lemma. Let us assume that the cost function (Morey, 2002), 


$$
c=c(y, w)
$$

represents minimum costs of production $y$ based on wage $w$. Therefore,

$$
c=c(y, w)=\underbrace{w^{\prime} x(y, w)}
$$

where $w^{\prime} x(y, w)$ is a conditional input demand function. Hence, $c(y, w)$ is the function value, i.e. minimum, instead of maximum. To make the understanding of this easier, $x$ is a scalar (only 1 input). If we apply envelope theorem

$$
\frac{\partial_{c}(y, w)}{\partial_{w i}}=\frac{\partial\left[w^{f} x(y, w)\right]}{\partial_{w i}}=\frac{\partial\left(w^{\prime} x\right)}{\partial_{w i}} / x=x(x, w)=x_{i}(y, w)
$$

we shall get the conditional input demand function for input $i$.

Shephard's lemma states that the demand for any factor of production is based on difference in price. In a transition country or an undeveloped country, labor market is represented as

$$
L_{s}\left(\frac{w_{s}}{w_{s}}\right)=\int_{0}^{x^{*}} \beta \theta\left[\frac{r_{s}}{w_{s} \alpha_{L}(c)+w_{s} \alpha_{H}(c)}\right] 1^{-0} \alpha_{L}(c) x_{s}(c) d c
$$

and

$$
H_{s}\left(\frac{w_{s}}{w_{s}}\right)=\int_{0}^{x^{*}} \beta \theta\left[\frac{r_{s}}{w_{s} \alpha_{L}(c)+w_{s} \alpha_{H}(c)}\right] 1^{-0} \alpha_{H}(c) x_{s}(c) d c
$$

Due to mobility of capital in the world market, there is an impact on real wages and employment. FDI inflow significantly determines the demand for skilled and unskilled labor. Relative demand for skilled labor in a transition country is specified as

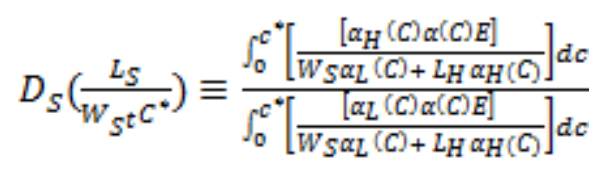

The best known flexible cost functions are the duals of the transcendental logarithmic production function (translog - TL) and the generalized Leontief production function (GL) (Dumont, 2006). The demand for production factors like skilled and unskilled labour is straightforwardly derived from a cost function. Flexible function specifications impose as little restrictions as possible. In order to reduce complexity, the industry subscripts are temporarily dropped (Geishecker, 2002),

$$
\ln c v=\alpha_{0}+\beta_{H S} \ln W^{H S}+\beta_{L S} \ln W^{L S}
$$




$$
\begin{gathered}
+1 / 2_{\gamma H S L S} \ln W^{H S} \ln W^{L S}+1 / 2_{\gamma L S H S} \ln W^{L S} \ln W^{H S} \\
+1 / 2_{\gamma H S H S} \ln W^{H S} \ln W^{H S}+1 / 2_{\gamma L S L S} \ln W^{L S} \ln W^{L S} \\
+\delta_{K} \ln \frac{K}{Y} \ln W^{L S}+1 / 2 \delta_{K K} \ln \frac{K}{Y} \ln \frac{K}{Y} \\
+\varphi_{K L S} \ln \frac{K}{Y} \ln W^{L S}+\varphi_{K H S} \ln \frac{K}{Y} \ln W^{H S} \\
+\eta_{T} T+1 / 2 \eta_{T T} T^{2}+\eta_{K T} T \ln \frac{K}{Y} \\
+\eta_{L S T} T \ln W^{L S}+\eta_{K T} T \ln W^{H S} \\
+\phi_{O} \text { Outs }+1 / 2 \phi_{O O} \text { Outs }{ }^{2}+\phi_{O} \text { Outs } \ln \frac{K}{Y} \\
+\phi_{L S I O} \text { Outs } \ln W^{L S}+\phi_{H S O} \text { Outs } \ln W^{H S}
\end{gathered}
$$

In order to impose symmetry and homogeneity on the cost function, the following parameter restrictions are required (Geishecker, 2002),

$$
\begin{gathered}
\gamma_{H S L S}=\gamma_{L S H S} \\
\beta_{H S}+\beta_{L S}=1 \\
\gamma_{H S H S}+\gamma_{H S L S}=\gamma_{L S L S}+\gamma_{L S H S}=0 \\
\varphi_{K H S}+\varphi_{K L S}=0 \\
\eta_{H S T}+\eta_{L S T}=0
\end{gathered}
$$

The unit cost function can be approximated by a general translog function with variable and quasi fixed input factors. Differentiation of the variable cost function with respect to prices of the variable factors gives the respective factor demand equation. Since the cost function is in logarithmic form, differentiation yields the factor's share in total variable costs (Geishecker, 2002), 


$$
\begin{aligned}
& \frac{\partial \ln C V}{\partial \ln W^{H S}}=\frac{W^{H S}}{C V} x \frac{\partial \ln C V}{\partial \ln W^{H S}}=\frac{W^{H S} S_{L}^{H S}}{C V}=S^{H S} \\
& \frac{\partial \ln C V}{\partial \ln W^{L S}}=\frac{W^{L S}}{C V} x \frac{\partial \ln C V}{\partial \ln W^{L S}}=\frac{W^{L S} L^{L S}}{C V}=S^{L S}
\end{aligned}
$$

$S^{H S}$ and $S^{L S}$ denote the cost share of skilled and unskilled labor in variable costs. Since skilled and unskilled labor are the only variable inputs, both factor share equations have to add up to one and only one of them is linearly independent.

In order to calculate the effect of FDI inflow on average real wage of skilled and unskilled labor, we applied translog cost function. This cost function has the useful property that its first derivative with respect to factor returns gives the factor cost shares. Accordingly, output and capital can be treated as fixed in the short run, while skilled and unskilled labor represent variable factors in the long run. We assume the production function $f_{\text {ic }}$ is increasing and concave $\left(L_{i \varepsilon}, H_{i e}, K_{i e}\right)$. The short-run cost function, obtained when the levels of capital and output are fixed but labour and intermediate inputs are flexible, is defined as (Foster et al., 2012),

$$
C_{i c}\left(W_{\text {Lic }}, W_{H i c}, K_{i c}, Y_{i c}\right)=\min _{L, H} W_{\text {Lie }}+W_{\text {Hic }}
$$

where $L$ is unskilled labor, $H$ skilled labor and $K$ is capital. Translog cost function can be presented as follows (Hijzen et al., 2003),

$$
\begin{aligned}
& \ln C_{i}= \\
& \alpha_{o}+\sum_{j=1}^{J} \alpha_{j} \ln w_{i j}+\sum_{k=1}^{K} \beta_{k} \ln x_{i k}+\frac{1}{2} \sum_{j=1}^{J} \sum_{s=1}^{J} \gamma_{j s} \ln w_{i j} \ln w_{i s}+ \\
& \frac{1}{2} \sum_{k=1}^{K} \sum_{l=1}^{K} \delta_{k l} \ln x_{i k} \ln x_{i l}+\sum_{j=1}^{J} \sum_{s=1}^{J} \varphi_{j k} \ln w_{i j} \ln x_{i k}
\end{aligned}
$$

where $C_{i}$ is the variable cost for industry $i=1, \ldots, I, w_{i j}$ denotes wages of the optimal skill-mix of workers for skill group $j=, \ldots, j$, i $x_{i k}$ denotes fixed inputs or outputs $k=1, \ldots, K$.

Translog cost function is presented as follows (Feenstra and Hanson, 1995),

$$
W S H_{i j t}=\beta_{H}+\beta_{V A} \ln \left(V A_{i j t}\right)+\delta_{H} \ln \left(w_{i j t}\right)+\beta_{k} \ln \left(K_{i j t}\right)+\eta_{i j t}
$$


where $W_{S H} H_{i j t}$ is the share of skilled labor in total labor costs and $\eta_{i j t}$ represents shocks to labor demand.

Control of factors affecting labor demand in in a certain country or industry is expressed in first-differenced form,

$$
\Delta W S H_{i j t}=\beta_{V A} \Delta \ln \left(V A_{i j t}\right)+\delta \Delta \ln \left(\frac{L_{i j t}}{W_{i j t}}\right)+\beta_{K} \Delta \ln \left(K_{i j t}\right)+\Delta \eta_{i j t}
$$

where $K_{i j t}$ is the total capital stock in industry $i j$, which represents the sum of the domestic and the foreign capital stock. The effect of foreign capital on relative labor demand is expressed by the equation below,

$$
\Delta \ln \left(K_{i j t}\right)=\Delta \ln \left(K_{i j t}^{D}\right)+\ln \left(K_{i j t}^{F} / K_{i j t}^{D}\right)
$$

where $K_{i j t}^{D}$ is domestic capital stock and $K_{i j t}^{F}$ is foreign capital stock.

Owing to FDI, production inputs are being transferred from developed countries to transition or undeveloped countries. In transition countries, increase in production volume or in input use causes a rise in recruitment of skilled labor compared to unskilled labor. It is generally known that developed countries reach higher levels of technological advancement, which affects the increase in skilled labor demand. Increased FDI inflow to transition countries and outflow of FDI from developed countries results in an increase in skilled labor demand, while unskilled labor demand gets reduced.

\section{Econometric Approach and Data}

According to official statistics in $\mathrm{B} \& \mathrm{H}$, Austria is considered to have been the largest foreign investor into B\&H over the last two decades. With this in mind, we attempt to determine the effect of FDI inflow from Austria on the labor market development in B\&H. The research used the time series data for the period 2005 - 2014. The data was taken from the database of the Central Bank of B\&H, Agency for Statistics of B\&H, Institute for Statistics of the Federation B\&H, Republic of Srpska Institute of Statistics and the World Bank (World Data Indicators). Amounts of variables are presented in thousands of euros. All variables used are natural logarithms.

Empirical analysis has been divided into two parts. The first part studies the effect of independent variables on the dependent variables i.e. on the increase in relative wages for skilled and unskilled labor. The second part examines the effect of independent variables on the dependent variables i.e. on the increase in number of skilled and unskilled workers in the labor market. In order to measure the effect of FDI inflow from Austria to the labor market of $\mathrm{B} \& \mathrm{H}$, this paper applies the North-South model and OLS Regression. Within the econometric 


\section{Al Macrothink}

Business and Economic Research

ISSN 2162-4860

2016, Vol. 6, No. 1

model, our dependent variables are the average wage for skilled labor, average wage for unskilled labor and the number of skilled and unskilled workers. Independent variables are gross fixed capital formation; foreign direct investment from Austria; industry value added; a total number of persons who completed elementary, secondary and tertiary education; a total number of employees in industry, services and agriculture sector. These variables were chosen based on the relevance of their impact on the explanation of the relationship between FDI and the labor market in B\&H. However, our analysis faced certain restrictions in terms of acquiring data on average wage for skilled and unskilled workers in industry, services and agriculture sector. We have also not been able to find data on cantons or entities with the most investments from Austria. Additionally, we have not been able to acquire data on the number of workers employed in foreign companies, as well as on their average real wages, which prevented us from determining the difference in wages between skilled and unskilled workers, as well as the difference in wages between foreign and local companies in $\mathrm{B} \& \mathrm{H}$.

Empirical analysis comprises the following steps. Firstly, we introduced regression equations. Then, we applied the OLS model and measured the effect of independent variables on the dependent variables. Empirical specification of OLS regression is presented using four regression equations:

a)

$$
\begin{aligned}
& {\text { Skilled } \text { Wage }_{i t}=} \\
& \beta_{0}+\beta_{1} \text { Unskilled Wage }_{i t}+\beta_{2} \text { Gross FCF }_{i t}+\beta_{3} \text { Industry VA }_{i t}+\beta_{4} \text { FDI AUT }_{i t}+ \\
& \beta_{5} \text { Number of skilled } \\
& \text { it }
\end{aligned}
$$

b)

$$
\begin{aligned}
& \text { Unskilled Wage }_{i t}= \\
& \beta_{0}+\beta_{1} \text { Skilled Wage }_{i t}+\beta_{2} \text { Gross FCF }_{i t}+\beta_{3} \text { Industry VA }_{i t}+\beta_{4} \text { FDI AUT }_{i t}+ \\
& \beta_{5} \text { Number of skilled }_{i t}+\beta_{6} \text { Number of unskilled }{ }_{i t}+\ldots,+\varepsilon_{i t}
\end{aligned}
$$

c)

$$
\begin{aligned}
& \text { Number of skilled }_{i t}=\beta_{0}+\beta_{1} \text { Number of unskilled }_{i t}+\beta_{2} \text { Primary education }_{\text {it }}+ \\
& \beta_{3} \text { Secondary education }_{i t}+\beta_{4} \text { Higher education }_{i t}+\beta_{5} \text { Industry }_{i t}+ \\
& \beta_{6} \text { Service }_{i t}+\beta_{7} \text { Agriculture }_{i t}, \ldots,+\varepsilon_{i t}
\end{aligned}
$$

d)

$$
\begin{aligned}
& \text { Number of unskilled }_{i t}= \\
& \beta_{0}+\beta_{1} \text { Number of skilled }_{i t}+\beta_{2} \text { Primary education }_{i t}+ \\
& \beta_{3} \text { Secondary education }_{i t}+\beta_{4} \text { Higher education } \\
& { }_{i t}+\beta_{5} \text { Industry }_{i t}+ \\
& \beta_{6} \text { Service }_{i t}+\beta_{7} \text { Agriculture }_{i t}+\ldots+\varepsilon_{i t}
\end{aligned}
$$

where: 
- Skilled Wage - average wage for skilled labor;

- Unskilled Wage - average wage for unskilled labor;

- Gross FCF - gross fixed capital formation;

- FDI AUT - foreign direct investment from Austria;

- Industry VA - industry value added;

- Number of skilled - number of skilled workers;

- Number of unskilled - number of unskilled workers;

- Primary education - number of persons who completed primary education;

- Secondary education - number of persons who completed secondary education;

- Higher education - number of persons who completed tertiary education;

- Industry - number of employees in industry sector;

- Service - number of employees in services sector;

- Agriculture - number of employees in agriculture sector.

\section{Estimation Results}

Within the first part of the research, we start with the analysis of the results given in Table 1 pertaining to the amount of average real wage for skilled labor in B\&H. Based on estimates provided in Table 1, it is evident that most independent variables positively affect the increase in average real wage for skilled labor in B\&H. In accordance with this, we emphasize that the effect of average real wage for unskilled labor (Unskilled Wage) is statistically significant at the 5 percent level, i.e. that it positively impacts the increase in average real wage for skilled labor (SkilledWage). Over the last two decades, the increase in real wage for 


\section{Al Macrothink}

Business and Economic Research

ISSN 2162-4860

2016, Vol. 6, No. 1

skilled labor has brought about an increase in skilled labor demand and lead to requalification of unskilled workers into skilled workers. In the case of gross fixed capital formation

(Gross FCF), we determined statistical significance at the 5 percent level i.e. its positive effect on the increase in average real wage for skilled labor. Over the last two decades, gross fixed capital formation in $\mathrm{B} \& \mathrm{H}$ has increased on a year-by-year basis, which positively impacts the increase in the number of skilled workers and the average real wage for skilled labor. Industry value added (Industry VA) is statistically significant at the 5 percent level, i.e. it positively affects the increase in the average real wage for skilled labor. Industrial production of finished and semi-finished products has grown over the greater portion of the analyzed period, which positively affected the increase in real wages for skilled labor. This tendency of industrial production to grow is expected to continue in the future, which will positively impact the labor market.

Table 1. Average real wage for skilled labour in B\&H

\begin{tabular}{|c|c|c|c|c|}
\hline \multicolumn{4}{|c|}{ Dependent Variable: Skilled wage } & \\
\hline \multicolumn{4}{|l|}{ Method: Least Squares } & \\
\hline \multicolumn{4}{|l|}{ Sample (adjusted): 19} & \\
\hline \multicolumn{4}{|c|}{ Included observations: 9 after adjustments } & \\
\hline Variable & Coefficient & Std. Error & t-Statistic & Prob. \\
\hline Unskilled Wage & 4.853569 & 0.296827 & 16.35151 & 0.0037 \\
\hline Gross FCF & 0.572439 & 0.094617 & 6.050055 & 0.0262 \\
\hline Industry VA & 6.022976 & 0.616064 & 9.776544 & 0.0103 \\
\hline Number of skilled & 2.597833 & 0.549336 & 4.729046 & 0.0419 \\
\hline Number of unskilled & 2.576607 & 0.395092 & 6.521534 & 0.0227 \\
\hline FDI AUT & 0.366717 & 0.033689 & 10.88530 & 0.0083 \\
\hline C & 58.86920 & 5.498478 & 10.70645 & 0.0006 \\
\hline R-squared & 0.995797 & \multicolumn{2}{|c|}{ Mean dependent var } & 6.049976 \\
\hline Adjusted R-squared & 0.983187 & \multicolumn{2}{|c|}{ S.D. dependent var } & 0.159252 \\
\hline S.E. of regression & 0.020649 & \multicolumn{2}{|c|}{ Akaike info criterion } & 4.870792 \\
\hline Sum squared resid & 0.000853 & \multicolumn{2}{|c|}{ Schwarz criterion } & 4.717395 \\
\hline Log likelihood & 28.91857 & \multicolumn{3}{|c|}{ Hannan-Quinn criter. 5.201822} \\
\hline F-statistic & 78.97073 & \multicolumn{2}{|c|}{ Durbin-Watson stat } & 2.020511 \\
\hline $\operatorname{Prob}($ F-statistic) & 0.002557 & & & \\
\hline
\end{tabular}

Note: *- significance at 10 percent level, $* *$ - significance at 5 percent level, $* * *$ - significance at 1 percent level.

Source: Author's

Total number of skilled workers (Number of skilled) is statistically significant at the 5 percent level, i.e. it positively impacts the increase in the average real wage for skilled labour. Due to an increase in industry value added, gross fixed capital formation and other factors' 
impacts, there has been an increase in the total number of recruited skilled workers and their real wages. Also, the total number of unskilled workers (Number of unskilled) is statistically significant at the 5 percent level, i.e. it positively impacts the increase in the average real wage for skilled labour. Positive trends in industry sector lead to a higher rate of re-skilling of unskilled workers thus reducing the pool of unskilled labor, which positively affected the increase in wages for skilled and unskilled labor. Finally, FDI from Austria are statistically significant at the 5 percent level, i.e. they positively impact the increase in average real wage for skilled labor. Statistically speaking, according to the amount of FDI inflow (FDI AUT), Austria is considered to be the largest of all foreign investors into $\mathrm{B} \& \mathrm{H}$. Significant presence of Austrian investments in the total share of FDI inflow into B\&H positively affected the increase in real wages for skilled labor. Austrian investments are mostly present in the manufacturing and services sector.

Table 2 contains the results of the research on the effect of independent variables on the increase in the average real wage for unskilled labor in B\&H. The average real wage for skilled labor (SkilledWage) is statistically significant at the 5 percent level, i.e. it positively impacts the increase in the average real wage for unskilled labor (Unskilled Wage) in $\mathrm{B} \& \mathrm{H}$. The demand for skilled labor in $\mathrm{B} \& \mathrm{H}$ has grown over the period under observation, albeit with certain minor oscillations, resulting in initiation of the requalification program for unskilled workers, which finally caused an increase in demand for unskilled labor and in the average real wage for unskilled labor. In regard to gross fixed capital formation (Gross $F C F$ ), we determined statistical significance at the 5 percent level i.e. its positive effect on the increase in average real wage for unskilled labor. An increase in gross fixed capital formation has lead to an increase in demand for unskilled labor and, consequently, to an increase in real wages. Higher presence of unskilled labor is particularly noticeable in construction and commercial and transport infrastructure sector. Industry value added (Industry $V A$ ) is statistically significant at the 5 percent level, i.e. it positively impacts the increase in the average real wage for unskilled labor. Industrial production of finished and semi-finished products has particularly grown in the industry sector, which positively affected the increase in demand for unskilled labor and in real wages for unskilled labor.

Table 2. Average real wage for unskilled labor in $\mathrm{B} \& \mathrm{H}$

\begin{tabular}{|l|l|l|l|}
\hline \multicolumn{2}{|l|}{ Dependent Variable: Unskilled wage } & \\
\hline Method: Least Squares & & \\
\hline Sample (adjusted): 19 & & \\
\hline Included observations: 9 after adjustments & & \\
\hline Variable $\quad$ Coefficient & Std. Error & t-Statistic & Prob. \\
\hline
\end{tabular}




\begin{tabular}{|l|r|r|r|r|}
\hline Skilled Wage & 0.204504 & 0.012507 & 16.35151 & 0.0037 \\
\hline Industry VA & 1.239394 & 0.110402 & 11.22619 & 0.0078 \\
\hline Number of skilled & -0.535589 & 0.107078 & -5.001839 & 0.0377 \\
\hline Number of unskilled & -0.529718 & 0.078366 & -6.759508 & 0.0212 \\
\hline FDI AUT & 0.075672 & 0.004223 & 17.91977 & 0.0031 \\
\hline Gross FCF & 0.117228 & 0.020236 & 5.792938 & 0.0285 \\
\hline C & 12.13278 & 0.826187 & 14.68527 & 0.0005 \\
\hline R-squared & 0.999028 & Mean dependent var & 5.791626 \\
\hline Adjusted R-squared & 0.996111 & S.D. dependent var & 0.067969 \\
\hline S.E. of regression & 0.004239 & Akaike info criterion & -8.037673 \\
\hline Sum squared resid & $3.59 E-05$ & Schwarz criterion & -7.884276 \\
\hline Log likelihood & 43.16953 & Hannan-Quinn criter. & 8.368703 \\
\hline F-statistic & 342.5194 & Durbin-Watson stat & 2.031201 \\
\hline Prob(F-statistic) & 0.002914 & \multicolumn{4}{|l|}{} & \\
\hline
\end{tabular}

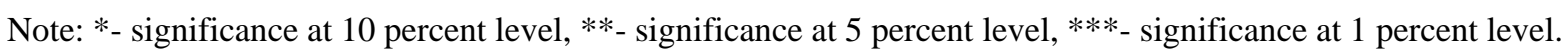

Source: Author's

Total number of skilled workers (Number of skilled) is statistically significant at the 5 percent level, i.e. it positively impacts the increase in the average real wage for unskilled labor. Due to an increase in industry value added, gross fixed capital formation and other factors' positive impacts, there has been an increase in the skilled labor employment rate, which caused an increase in real wages. Total number of unskilled workers (Number of unskilled) is statistically significant at the 5 percent level, i.e. it positively impacts the increase in the average real wage for unskilled labor. Increase in demand for unskilled labor affects the increase in real wages for unskilled labor. Increase in real wages for unskilled labor is ascribed to significant FDI inflow in the labor-intensive manufacturing sector. Finally, foreign direct investments from Austria (FDI AUT) are statistically significant at the 5 percent level, thus positively affecting the increase in average real wage for unskilled labor. The increase in real wage for unskilled labor is mostly attributed to Austria's traditional investment into manufacturing sector of $\mathrm{B} \& \mathrm{H}$.

In the second part of our research, i.e. in Table 3, we estimated that the increase in number of skilled workers is positively affected by a great number of independent variables. Firstly, we concluded that the number of persons who completed primary education (Primary education) is not statistically significant at the 5 percent level, i.e. does not have a positive impact on the increase in the number of skilled workers. Over the last decade, $\mathrm{B} \& \mathrm{H}$ has registered a decline in the number of students enrolled in primary schools as a result of reduced natality during the war and post-war period, which negatively affected the number of skilled workers. The number of persons who completed secondary education 
(Secondary education) is statistically significant at the 5 percent level, i.e. positively affects the supply of skilled labor. This positive impact of secondary education on the increase in the number of skilled workers is attributed to a smaller number of persons opting for higher education and to strengthening of the industry sector relying on skilled labor. The number of persons who completed tertiary education (Highereducation) is not statistically significant at the 5 percent level, i.e. it does not positively impact the number of skilled workers.

Table 3. Number of skilled workers in B\&H

\begin{tabular}{|l|r|r|r|r|}
\hline Dependent Variable: Number of skilled & \\
\hline Method: Least Squares & & & \\
\hline Sample: 110 & Coefficient & Std. Error & t-Statistic & Prob. \\
\hline Included observations: 10 & -7.791668 & 4.709964 & -1.654294 & 0.2399 \\
\hline Primary education & 49.14564 & 7.659599 & 6.416215 & 0.0234 \\
\hline Secondary education & 84.18455 & 27.42736 & 3.069364 & 0.0918 \\
\hline Higher education & 185.6274 & 38.47121 & 4.825098 & 0.0404 \\
\hline Industry & 294.1467 & 46.25899 & 6.358693 & 0.0239 \\
\hline Service & -2.930791 & 24.43537 & -0.119941 & 0.9155 \\
\hline Agriculture & 1.920811 & 0.128440 & 14.95490 & 0.0044 \\
\hline Number of unskilled & 35186.23 & 3888.270 & 9.049328 & 0.0020 \\
\hline C & 0.995863 & Mean dependent var & 93664.10 \\
\hline R-squared & 0.981386 & S.D. dependent var & 2975.924 \\
\hline Adjusted R-squared & 406.0177 & Akaike info criterion & 14.84123 \\
\hline S.E. of regression & 329700.8 & Schwarz criterion & 15.08330 \\
\hline Sum squared resid & -66.20616 & Hannan-Quinn criter. & 14.57568 \\
\hline Log likelihood & 68.78568 & Durbin-Watson stat & 2.005014 \\
\hline F-statistic & 0.000403 & & & \\
\hline Prob(F-statistic) & & & \\
\hline
\end{tabular}

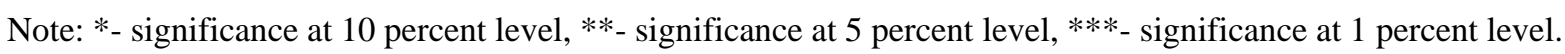
Source: Author's

With respect to the number of employees in industry sector (Industry), we have determined that it is statistically significant at the 5 percent level, i.e. it positively impacts the skilled labor pool. Growth of the industry sector is considered to be an important factor affecting the increase in the number of skilled workers. Also, the number of employees in services sector (Service) is statistically significant at the 5 percent level, i.e. it positively affects the skilled labor supply. In terms of significance, the services sector immediately follows the 
manufacturing sector in B\&H. However, in the case of the number of employees in agriculture sector (Agriculture) we have not determined a statistical significance at the 5 percent level, i.e. there is a negative effect on the skilled labor pool. The state of the agriculture sector in $\mathrm{B} \& \mathrm{H}$ is very difficult and its effect on the increase in the number of skilled workers is negligible. Lastly, the number of unskilled workers (Number of unskilled) is statistically significant at the 5 percent level, i.e. it positively affects the increase in the number of skilled workers. Unskilled labor affects the increase in the number of skilled workers, in such a manner that the increase in skilled labor demand leads to requalification of unskilled workers.

In table 4, we concluded that, just as in the case of skilled workers, the number of persons who completed primary education (Primary education) is not statistically significant at the 5 percent level, i.e. it does not positively affect the growth of unskilled labor pool. The number of persons who completed secondary education (Secondary education) is statistically significant at the 5 percent level, i.e. it positively affects the unskilled labor pool. This positive effect of secondary education on the growth of unskilled labor pool can be attributed to the reduced number of students who finish high school. The number of persons who completed tertiary education (Higher education) is not statistically significant at the 5 percent level, i.e. it does not have a positive impact on unskilled labor pool. This kind of result for higher education was expected.

Table 4. Number of unskilled workers in B\&H

\begin{tabular}{|c|c|c|c|c|}
\hline \multicolumn{4}{|c|}{ Dependent Variable: Number of unskilled } & \\
\hline \multicolumn{3}{|l|}{ Method: Least Squares } & & \\
\hline \multicolumn{2}{|l|}{ Sample: 110} & & & \\
\hline \multicolumn{3}{|c|}{ Included observations: 10} & & \\
\hline Variable & Coefficient & Std. Error & t-Statistic & Prob. \\
\hline Primary education & 3.930438 & 2.527776 & 1.554900 & 0.2602 \\
\hline Secondary education & 25.62229 & 3.453606 & 7.418997 & 0.0177 \\
\hline Industry & 96.77845 & 18.51549 & 5.226891 & 0.0347 \\
\hline Service & 153.5900 & 20.03526 & 7.665986 & 0.0166 \\
\hline Agriculture & 2.215203 & 12.61346 & 0.175622 & 0.8768 \\
\hline Number of skilled & 0.515999 & 0.034504 & 14.95490 & 0.0044 \\
\hline Higher education & -44.16152 & 13.37466 & -3.301880 & 0.0808 \\
\hline C & 17888.48 & 3218.364 & 5.558251 & 0.0009 \\
\hline R-squared & 0.997196 & \multicolumn{2}{|c|}{ Mean dependent var } & 31691.60 \\
\hline Adjusted R-squared & 0.987383 & \multicolumn{2}{|c|}{ S.D. dependent var } & 1873.490 \\
\hline S.E. of regression & 210.4395 & \multicolumn{2}{|c|}{ Akaike info criterion } & 13.52684 \\
\hline
\end{tabular}




\begin{tabular}{|c|c|c|c|}
\hline Sum squared resid & 88569.55 & Schwarz criterion & 13.76890 \\
\hline Log likelihood & -59.63418 & Hannan-Quinn criter. & 13.26129 \\
\hline F-statistic & 101.6187 & Durbin-Watson stat & 2.025402 \\
\hline Prob(F-statistic) & 0.009779 & & \\
\hline
\end{tabular}

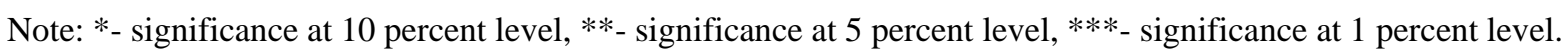

Source: Author's

With regard to the number of employees in industry sector (Industry), we determined statistical significance at the 5 percent level, i.e. its positive effect on unskilled) labor pool. Growth of industry sector is considered to be an important cause of increase in the number of unskilled workers. The number of employees in services sector (Service) is statistically significant at the 5 percent level, i.e. it positively affects the unskilled labor pool. However, the number of employees in agriculture sector (Agriculture) is not statistically significant at the 5 percent level, i.e. it negatively affects the unskilled labor pool. The state of the agriculture sector in $\mathrm{B} \& \mathrm{H}$ has been very difficult; hence, the number of unskilled workers employed in it has been decreasing on a year-on-year basis. Finally, the number of skilled workers (Number of skilled) is statistically significant at the 5 percent level, i.e. it positively affects the increase in the number of unskilled workers.

\section{Conclusion}

In the last few decades, there has been some controversy regarding the role and significance of FDI. According to the dominant opinion, FDI is considered to be an important generator of economic development in transition countries. On the other hand, FDI is seen as a very speculative form of business that negatively affects the economy of transition countries i.e. their labor markets. With respect to the dominant opinion, FDI lead to the establishment of new manufacturing capacities, development of services sector, transfer of knowledge and skills and the like, which finally results in creating new jobs. In developed countries, outflow of FDI is thought to lead to an increase in unemployment, while the prevailing opinion in undeveloped countries is that FDI inflow leads to creation of new jobs. Accordingly, we pose the question whether FDI lead to an increase in real wage for skilled and unskilled labor and to a rise in the number of skilled and unskilled workers in transition countries.

FDI strongly affect the shaping of the structure of labor markets in the host countries. In this light, we studied the effect of FDI inflow from Austria on the composition of labor market in $\mathrm{B} \& \mathrm{H}$ in terms of the amount of real wage and the number of workers according to skill level. The research is divided into two parts. Within the first part, we studied the effect of independent variables such as average real wage for unskilled labor, average real wage for skilled labor, gross fixed capital formation, industry value added, total number of skilled workers and FDI from Austria on the increase in average real wage for skilled and unskilled labor in $\mathrm{B} \& \mathrm{H}$. The analysis results have shown that independent variables have a statistically 
significant effect on the increase in average real wage for skilled labor in B\&H. Owing to the positive trends in the growth rates of industrial production, gross fixed capital formation and FDI inflow from Austria, there has been an increase in demand for skilled labor i.e. a cumulative rise in average real wage for skilled labor. Additionally, we have reached the same results with regard to increase in average real wage for unskilled labor, i.e. that independent variables have a statistically significant effect on the increase in average real wage for unskilled labor. Principally, increase in average real wage for unskilled labor is the result of increase in industrial production, which registers a growing demand for unskilled labor, as well as of the reduced number of unskilled workers due to intensified requalification process.

In the second part of our research we studied the effect of independent variables such as the number of persons who finished primary, secondary and tertiary education and the number of employees in industry, services and agriculture sector on the total number of skilled workers in $\mathrm{B} \& \mathrm{H}$. The research has shown that the effect of independent variables on the total number of skilled workers is statistically significant, i.e. that variables such as the number of persons who finished primary, secondary and tertiary education, the number of employees in industry, services and agriculture sector and the number of unskilled workers positively affect the number of skilled workers in B\&H. We have also reached an identical result i.e. that independent variables such as the number of persons who finished primary, secondary and tertiary education, the number of employees in industry, services and agriculture sector and the number of skilled workers have a statistically significant effect on the number of unskilled workers in B\&H. This piece of data tells us that FDI inflow from Austria positively affects the increase in the number of recruited skilled workers, thus confirming the results of earlier research conducted in transition and developing countries, while the piece of data regarding the increase in the number of unskilled workers is atypical and is characteristic only of B\&H. One of the reasons for such a state is that a greater portion of FDI goes to industry sector dominated by labor-intensive production. Lastly, increase in FDI from Austria and other significant investor countries into $\mathrm{B} \& \mathrm{H}$ could have a positive impact on the increase in the number of skilled and unskilled workers, increase in real wages and the improvement in the standard of living, and, in the long run, it could lead to development of competitive economy.

\section{References}

Almeida, K. R., \& Lince de Faria, M. (2014). The Wage Returns to On-the-Job Training: Evidence from Matched Employer-Employee Data. Discussion Paper No. 8314. Institute for the Study of Labor. Retrieved from http://ftp.iza.org/dp8314.pdf

Bartlett, W., \& Arandarenko, M. (2012). The Labour Market, Skills and Growth in the Western Balkans: An introduction. In: W. Bartlett, and M. Arandarenko (Eds.), Labour Market and Skills in the Western Balkans (pp. 3-15). LSEE is part of the LSE's European Institute. Belgrade. Retrieved from http://www.lse.ac.uk/europeanInstitute/research/LSEE/PDFs/Skills\&thelabourmarket.pdf

Bassanini, A. (2004). Improving skills for more and better jobs? The quest for efficient policies to promote adult education and training. European Economy: Special Reports. 
Retrieved from http://halshs.archives-ouvertes.fr/halshs-00169612/document

Borjas, J. G., \& Ramey, A. V. (1993). Foreign Competition, Market Power, and Wage Inequality: Theory and Evidence. Working Paper No. 4556. National Bureau of Economic Research, Cambridge, MA. Retrieved from http://www.nber.org/papers/w4556.pdf

Bruno, S. F. G., Crinò, R., \& Falzoni, M. A. (2004). Foreign Direct Investment, Wage Inequality and Skilled Labor Demand in EU Accession Countries. Working Papers No. 154. Centro di Ricerca sui Processi di Innovazione Internazionalizzazione. Milano. Retrieved from ftp://ftp.unibocconi.it/pub/RePEc/cri/papers/WP154FalzoniBrunoCrino.pdf

Castellani, D., Mariotti, I., \& Piscitello, L. (2006). Outward investments and skill upgrading. Evidence from the Italian case. Working Papers No. 185, Centro di Ricerca sui Processi di Innovazione e Internazionalizzazione Università Commerciale Luigi Bocconi. Retrieved from ftp://ftp.unibocconi.it/pub/RePEc/cri/papers/WP185CastellaniMariottiPiscitello.pdf

Checchi, D., De Simone G., \& Faini, R. (2007). Skilled Migration, FDI and Human Capital Investment. Discussion Paper No. 2795. Institute for the Study of Labor. Bon. Retrieved from http://ftp.iza.org/dp2795.pdf

Commander, S., \& Kollo, J. (2004). The Changing Demand for Skills: Evidence from the Transition. Discussion Paper No. 1073. Institute for the Study of Labor. Bon. Retrieved from http://ftp.iza.org/dp1073.pdf

Cuyvers, L. Dhyne, E., \& Soeng, R. (2010). The effects of internationalisation on domestic labour demand by skills: Firm-level evidence for Belgium. Working Paper Research No. 206, In: J. Smets (Ed.), International trade: threats and opportunities in a globalised world (1-27). National Bank of Belgium. Retrieved from https://www.nbb.be/doc/oc/repec/reswpp/wp206en.pdf

Davies, R. B. Desbordes, R., \& Ray, A. (2015). Greenfield versus Merger \& Acquisition FDI: Same Wine, Different Bottles? Working Paper No. 03. UCD Centre for Economic Research. Retrieved from http://www.econstor.eu/bitstream/10419/109729/1/818314842.pdf

Davies, B. R., \& Desbordes, R. (2012). Greenfield FDI and Skill Upgrading. IIIS Discussion Paper No. 395. Institute for International Integration Studies. Retrieved from http://www.tcd.ie/iiis/documents/discussion/pdfs/iiisdp395.pdf

Dumont, M. (2006). Foreign outsourcing, labour demand and the choice of functional form. Journal of Applied Economics. Vol. IX, No. 2. Retrieved from http://www.ucema.edu.ar/publicaciones/download/volume9/dumont.pdf.

Foster, N. Stehrer, R., \& Vries De, G. (2012). Offshoring and the Skill Structure of Labour Demand. Working Papers No. 86. The Vienna Institute for international economics studies. Retrieved from http://wiiw.ac.at/offshoring-and-the-skill-structure-of-labour-demand-dlp-2638.pdf

Feenstra, C. R., \& Hanson, H. G. (1995). Foreign Direct Investment and Relative Wages: Evidence from Mexico's Maquiladoras. Working Paper No. 5122. National Bureau of 
Economic Research. Cambridge. MA. Retrieved from http://www.nber.org/papers/w5122

Feenstra, C. R., \& Hanson, H. G. (1996). Globalization, Outsourcing, and Wage Inequality. Working Paper No. 5424. National Bureau of Economic Research. Cambridge. MA. Retrieved from http://www.nber.org/papers/w5424.pdf

Feenstra, C. R. (2007). Globalization and Its Impact on Labour. Working Papers No. 44. The Vienna Institute for International Economics Studies. Retrieved from http://www.wiiw.ac.at/pdf/wp44.pdf

Geishecker, I. (2002). Outsourcing and the Demand for Low skilled Labour in German Manufacturing: New Evidence. Discussion Papers No. 313. German Institute for Economic Research, Berlin. Retrieved from http://www.gsoep.de/documents/publikationen/73/38648/dp313.pdf

Gashi, N. G., \& Adnett, A. (2012). Technology, training and transition: Evidence from the Western Balkans. Eastern European Economics. Vol. 50, Issue 6, 1-31. http://dx.doi.org/10.2753/eee0012-8775500603

Goczek, L. (2013). Firm Level Analysis of FDI and Social Development. Working Papers No. 7 (92). Faculty of Economic Sciences. University of Warsaw. Retrieved from http://www.wne.uw.edu.pl/inf/wyd/WP/WNE_WP92.pdf

Hakkala, K., Heyman, F., \& Sjöholm, F. (2007). Cross-Border Acquisitions, Multinationals and Wage Elasticities. IFN Working Paper No. 709. Research Institute of Industrial Economics. Retrieved from http://www.ifn.se/Wfiles/wp/wp709.pdf

Hakkala, N. K., Heyman, F., \& Sjoholm, F. (2010). Multinationals, skills and wage elasticities. Review of World Economics. Vol. 146, Issue 2, 263-280. http://dx.doi.org/10.1007/s10290-009-0047-9

Hijzen, A., Görg, H., \& Hine, C. R. (2003). International Fragmentation and Relative Wages in the UK. Discussion Paper No. 717. The Institute for the Study of Labor. Bon. Retrieved from http://ftp.iza.org/dp717.pdf

Lipsey, E. R., \& Sjoholm, F. (2001). Foreign Direct Investment and Wages in Indonesian Manufacturing. Working Paper No. 8299. National Bureau of Economic Research. Cambridge. MA. Retrieved from http://www.nber.org/papers/w8299

Lipsey, E. R. (2002). Home and host country effects of FDI. Working Paper No. 9293. National Bureau of Economic Research. Cambridge. MA. http://www.nber.org/papers/w9293

Markusen, R. J., \& Venables, J. A. (1996). Multinational Production, Skilled Labor, and Real Wages. Working Paper No. 5483. National Bureau of Economic Research. Cambridge. MA. Retrieved from http://www.nber.org/papers/w5483.pdf

Mattes, A. (2010). The Impact of Horizontal and Vertical FDI on Labor Demand for Different Skill Groups. IAW Diskussionspapiere No. 59. Institut for Angewandte Wirtschaftsforschung. Retrieved from http://www.iaw.edu/RePEc/iaw/pdf/iaw_dp_59.pdf 


\section{Macrothink}

Business and Economic Research ISSN 2162-4860 2016, Vol. 6, No. 1

Morey, R. E. (2002). The Envelope Theorem: Shephard's Lemma, Hotelling's Lemma, etc. February. Retrieved from http://www.colorado.edu/economics/morey/6808/envelope.pdf

Murphy, M. K., Riddell, C.W., \& Romer, M. P. (1998). Wages, Skills and Technology in the United States and Canada. Working Paper No. 6638. National Bureau of Economic Research. Cambridge. MA. Retrieved from http://www.nber.org/papers/w6638.pdf

Slaughter, J. M. (2002a). Skill Upgrading in Developing Countries: Has Inward Foreign Direct Investment Played a Role? Working Paper No. 192. Research programme on: Global Interdependence and Income Distribution, OECD Development Centre. Retrieved from http://www.oecd-ilibrary.org/development/skill-upgrading-in-developing-countries_2150326 76303

Slaughter, J. M. (2002b). Does Inward Foreign Direct Investment Contribute to Skill Upgrading in Developing Countries? CEPA Working Paper No. 08. Centre for Economic Policy Analysis. Retrieved from http://www.economicpolicyresearch.org/scepa/publications/workingpapers/2002/cepa200208. pdf

Tan, H. Savchenko, Y. Gimpelson, V. Kapelyushnikov, R., \& Lukyanova, A. (2007). Skills Shortages and Training in Russian Enterprises. Discussion Paper No. 2751. Institute for the Study of Labor. Retrieved from http://ftp.iza.org/dp2751.pdf

Tomiura, E., Ito, B., \& Wakasugi, B. (2011). Offshore outsourcing and non-production workers: Firm-level relationships disaggregated by skills and suppliers. Discussion Paper No. 760. Kyoto Institute of Economic Research. Retrieved from http://www.kier.kyoto-u.ac.jp/DP/DP760.pdf

\section{Appendix 1}

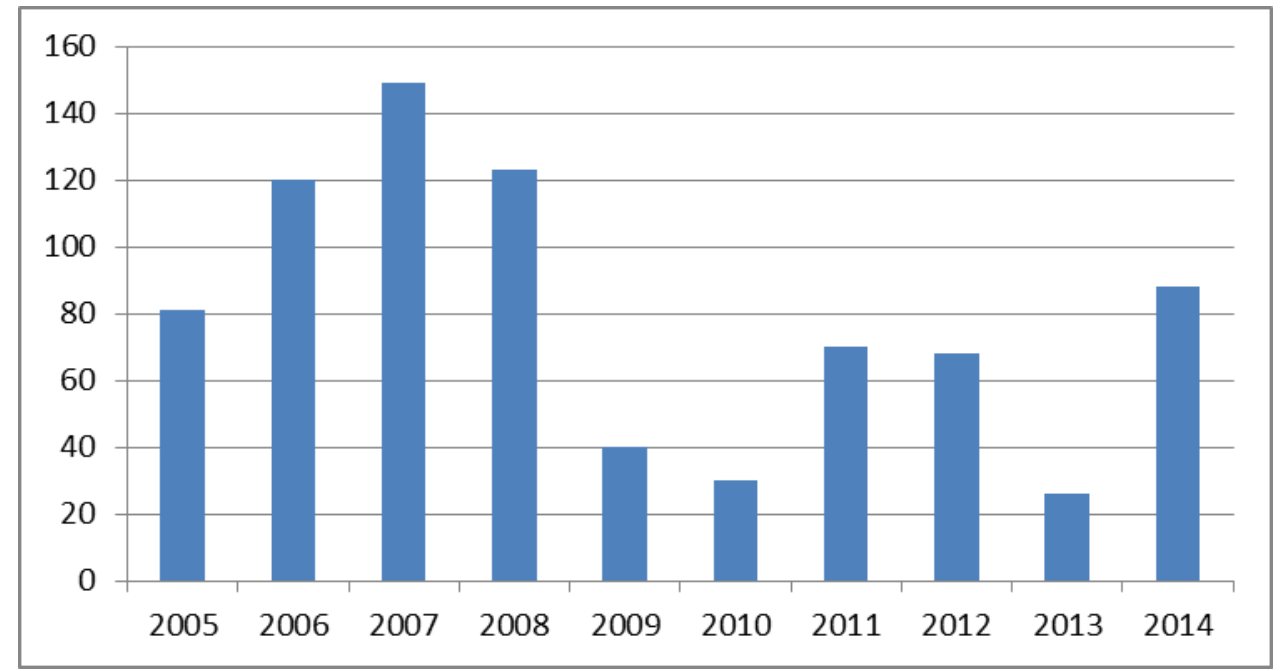

Figure. A1 FDI from Austria to B\&H, 2005 - 2014 (million euros) 


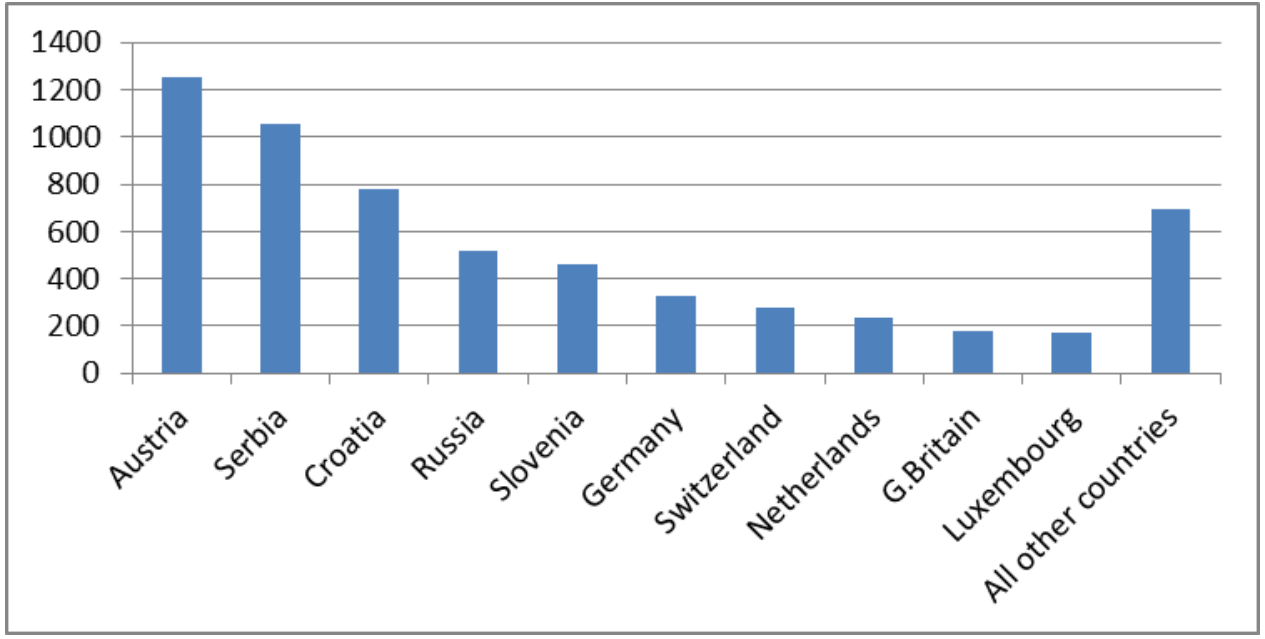

Figure. A2 Top investor countries in B\&H: 1994 - 2014 (million euros)

Source: Author's calculation based on the data acquired from the Foreign Investment Promotion Agency of $\mathrm{B} \& \mathrm{H}$

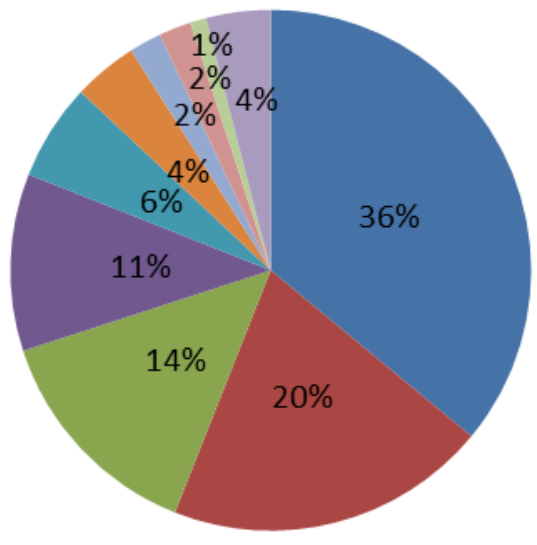

$$
\begin{aligned}
& \text { Manufacturing } \\
& \text { Banking } \\
& \text { - Telecommunication } \\
& \text { Trade } \\
& \text { Real estate } \\
& \text { - Service } \\
& \text { Other financial service } \\
& \text { - Tourism } \\
& \text { - Transport }
\end{aligned}
$$

Figure. A3 FDI Stocks by Industry: $1994-2014$

Source: Author's calculation based on the data acquired from the Foreign Investment Promotion Agency of $\mathrm{B} \& \mathrm{H}$ 


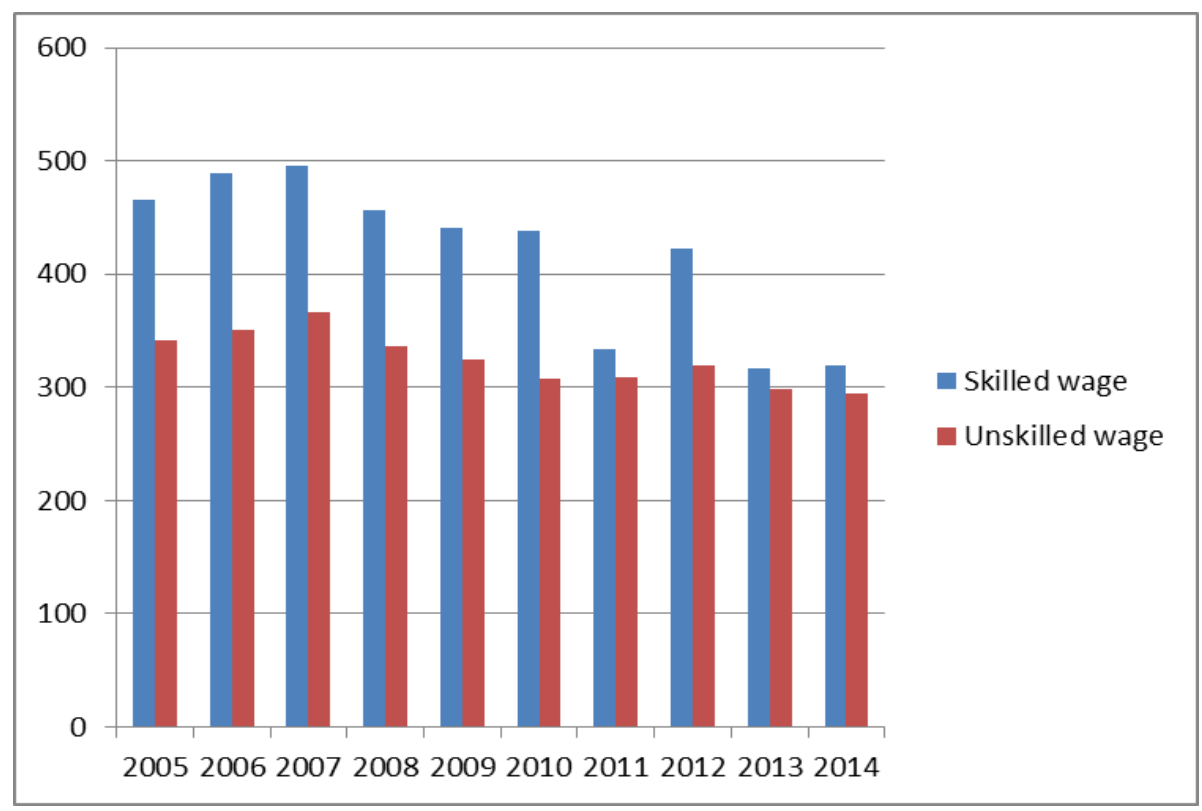

Figure. A4 Average real wage for skilled and unskilled labor in B\&H (hundred euros)

Source: Author's calculation based on the data acquired from the Institute for Statistics of the Federation B\&H and the Republic of Srpska Institute of Statistics.

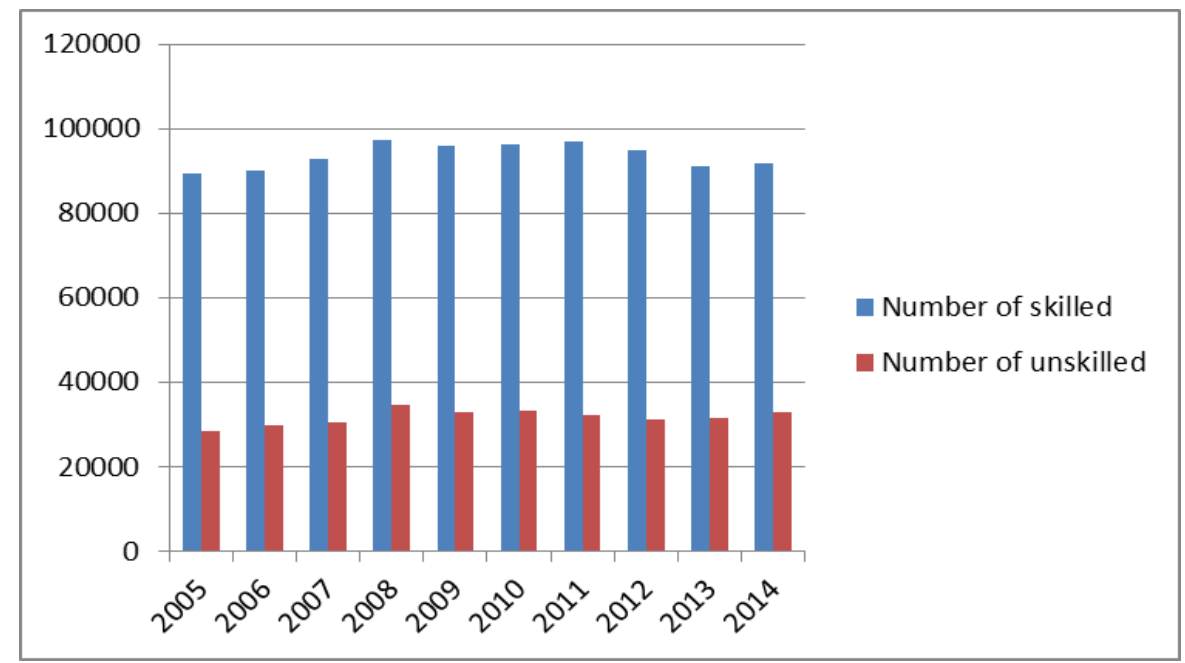

Figure. A5 Total number of skilled and unskilled workers in B\&H (thousand euros)

Source: Author's calculation based on the data acquired from the Institute for Statistics of the Federation B\&H and the Republic of Srpska Institute of Statistics.

\section{Copyright Disclaimer}

Copyright for this article is retained by the author(s), with first publication rights granted to the journal.

This is an open-access article distributed under the terms and conditions of the Creative Commons Attribution license (http://creativecommons.org/licenses/by/3.0/). 